\title{
ISAAC HENRY BURKILL
}

Born in 1870, dying on 7th March, 1965, Isaac Henry Burkill was, for 25 years, a member of this Society. Educated at Repton and (as a scholar) at Gonville and Caius College he was awarded the Walsingham Medal in 1891, the Paul Johannes Brühl Memorial Medal in 1934 and the Gold Medal of the Linnaean Society, which he served and adorned so long, in 1952. After taking his degree he became an Assistant Curator at Cambridge University Herbarium, then a Technical, and in 1899 a Principal Assistant at Kew, a reporter on Economic Products to the government of India in 1902, a post that greatly affected the future trend of his researches. He visited Nepal and Sikkim, and was botanist to the Abor expedition (1911-12). Finally from 1912 to 1925 he was director of Gardens, Singapore. He wrote many papers for various journals, e.g. on Oriental vernacular names of the Genus Dioscorea, on Malay Village Medicine Prescriptions, and chapters on the History of Botany in India, the last about to be published in book form. His greatest published work (which had it appeared during his official life must surely have won him an honour) was his encyclopaedic "Dictionary of the Economic Products of the Malay Peninsula." This work occupied him for ten years and is indispensable to any economist or historian writing on Malaya. Burkill was an unassuming and much liked man, who even forgave me for getting the site of the first Para rubber trees ever planted in Malaya taken from the Economic Gardens and included in the site of Singapore's University. He married his cousin Ethel Maud Morrison in 1910 and they had a son who holds his father's former post in Singapore.

R. O. WINSTEDT.

\section{DR. VICTOR PURCELL, C.M.G., Litt.D. (Cantab.)}

The late Dr. Purcell was born on 26th January, 1896, and died in his sleep at Cambridge three weeks before his 69 th birthday.

Educated at Bancroft's School and Trinity College, Cambridge, where he edited The Granta, he was an officer in the Green Howards (1915-18) and was twice wounded and taken prisoner. In 1921 he became a Cadet in the Malayan Civil Service, where he held a variety of posts in the Chinese Protectorate and in charge of Chinese vernacular education. In the second world war he was promoted Colonel in his old regiment and in 1945 became Principal Adviser on Chinese Affairs to the British Military Administration of Malaya. Having lectured in 1941 in the United States for the Ministry of Information, he was a consultant on various post-war commissions on Asia and the Far East. In 1955 he was a visiting lecturer at John Hopkins University and in Canada.

His published works include the Further Side of No-man's Land (1929), an account of his war experiences, the Sweeniad (a clever parody in verse of T. S. Eliot) (1957), followed by Toynbee in Elysium, and, as a result of his study in Canton, a book on the Spirit of Chinese Poetry and an Index to the Chinese Written Language (1929). But his main interest became history, when he wrote The Chinese in Malaya (1948), The Chinese in South-East 